groups within the Aspleniaceae. Puttock and Quinn (1980) had previously described 9 groups within Asplenium in Australia, considerably modifying the groups proposed by Holttum (1954). Four additional groups have been described from the present studies. It would appear that group 4, as defined by Puttock and Quinn, requires closer examination.

Both Diplora and Asplenium sect. Thamnopteris (Holttum 1974) show considerable variation in perispore morphology, each including representatives from at least three groups. Studies of the morphology and anatomy of Diplora indicate that it is polyphyletic in origin and consequently it should not be treated as a separate genus but as part of Asplenium. The New Guinea species of sect. Thamnopteris have a dense pattern of fimbria in the areolae but considerable variation occurs in the patterns of ridge development. Other species, not in sect. Thamnopteris, show similar perispore morphology.

Perispore morphology alone, like other morphological characters, will not provide a basis for erecting clearly defined groups. A wide variety of morphological, anatomical and cytological data will be necessary for understanding the relationships within the Aspleniaceae in Malesia.

Holttum, R. E. 1954. A Revised Flora of Malaya, Vol. II, Ferns of Malaya. Singapore: Government Printing Office.

- 1974. Aspleniaceae L. Sect. Thamnopteris. Gdns' Bull. Singapore 27, 143-154.

Puttock, C. F. and Quinn, C. J. 1980. Perispore morphology and taxonomy of the Australian Aspleniaceae. Aust. J. Bot. 2, 305-322.

\title{
Light and scanning electron microscope studies on the perispore in the genus Pyrrosia \\ Kunio Mitui
}

Department of Biology, Nippon Dental University, Hamaura Cho, 1-8, Niigata, Japan

Light and scanning electron microscope studies have been made on the spores of 17 species belonging to the genus Pyrrosia (including Drymoglossum and Saxiglossum). All of the species investigated have a perispore around the exospore, and the structures of perispores are diverse within the genus. As far as the present study is concerned, the perispores of this genus can be classified into the following three groups:

(1) A perispore of many verrucae, which are 6-10 $\mu \mathrm{m}$ high and $2-5 \mu \mathrm{m}$ wide, and a very thin membrane surrounding these verrucae. The perispore stains red with PAS reaction and appears dark blue in Giemsa staining. The following species belong to this group: $P$. rupestris, $P$. lanceolata, $P$. varia, $P$. longifolia, $P$. confluense, $P$. nummularifolia, Drymoglossum piloselloides and $D$. fallax.

(2) A perispore which is membraneous and stains red with PAS reaction, and makes a few folds. The following species are included in this group: $P$. winkeri and $P$. angustata. 
(3) A perispore which is composed of a thin membrane staining red with PAS reaction, and several spherical bodies that show light blue in the Giemsa staining like the exospore. The following species have perispore of this type: $P$. lingua, $P$. mollis, $P$. linearifolia, P. mannii, P. eberhardtii, $P$. tricuspis and Saxiglossum angustissinum.

From the recent detailed studies, it has become clear that several genera of Polypodiaceae have a perispore around the exospore. The well-developed perispore found in the genus Pyrrosia, however, has never been found in any other genera of this family.

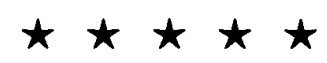

\title{
B. SPORE GERMINATION AND GAMETOPHYTE DEVELOPMENT
}

\section{Photocontrol of protonema growth in Polypodium vulgare L.}

\author{
Norma Agnew and D. L. Smith
}

Department of Botany, The Queen's University, Belfast BT7 1NN, U.K.

When imbibed spores of $P$. vulgare L. were given a short exposure to red light, germination was complete by day 7 and then protonema growth continued until day 12. If a second short exposure of red light was given on day 7 , protonema growth was enhanced and continued indefinitely if further exposures of red light were given at weekly intervals. If the red light was replaced by blue, similar effects were obtained but if it was replaced or followed by far-red light, protonema growth stopped. This red/far-red light response was repeatedly reversible and thus implicates phytochrome. The response entailed increase in cell division and length but not in cell width. The action spectra for cell division and elongation are essentially identical to those for spore germination and for other known low energy phytochrome responses.

When the exposure given on day 7 was prolonged for $24 \mathrm{~h}$ or more, two distinct high energy responses were recognisable. With blue light, cell number increased, cell length decreased and cell width increased; with far-red light, cell number and length increased but cell width decreased. Quantitatively, the effects of red light were intermediate between those of blue and far-red light. The simplest interpretation is that the blue light response is mediated by the uncharacterised blue light absorbing pigment, the far-red response is controlled by the high energy phytochrome reaction, while the response to red light involves both pigment systems. 